\title{
Exploring mathematization underpinnings of prospective mathematics teachers in solving mathematics problems
}

\author{
Lestariningsih $^{1}$, Siti M. Amin, Agung Lukito², Moch. Lutfianto ${ }^{3}$
}

\begin{abstract}
Abstrak: Tujuan penelitian ini adalah untuk mengeksplorasi matematisasi yang mendasari mahasiswa calon guru matematika dalam menyelesaikan masalah matematika. Penelitian ini menggunakan penelitian eksploratif dengan pendekatan kualitatif. Instrumen yang digunakan dalam penelitian ini adalah tes kemampuan matematika, masalah kontekstual, dan pedoman wawancara. Subjek penelitian adalah seorang mahasiswa calon guru dengan kemampuan matematika tinggi yang dipilih dari 56 mahasiswa dengan menggunakan tes kemampuan matematika. Setelah subjek penelitian menyelesaikan masalah kontekstual, dilakukan wawancara. Hasil penelitian menunjukkan bahwa mahasiswa calon guru matematika melakukan matematisasi yang sangat penting karena menyelesaikan masalah matematika dengan menyederhanakan masalah, menyelesaikan masalah secara terstruktur, dan diarahkan sesuai dengan konteks yang ada dalam masalah. Temuan dalam penelitian ini mengungkapkan bahwa melalui matematisasi dapat diketahui cara mahasiswa dalam merumuskan masalah kontekstual ke dalam soal matematis.
\end{abstract}

Kata kunci: Matematisasi, Mahasiswa calon guru, Pemecahan masalah, Masalah kontekstual

\begin{abstract}
The purpose of this study was to explore the mathematization underpinnings of prospective mathematics teacher on mathematical problem-solving. This study used explorative research with a qualitative approach. The instruments used in this study were mathematical ability test, contextual problems, and interview guidelines. A prospective mathematics teacher who has high mathematics ability involved in this study. The subject was selected from 56 prospective mathematics teachers through a test. After the subject solved contextual problems, an interview was conducted. The result revealed that prospective mathematics teacher did mathematization when solving the contextual problem by simplifying, solving in a structural way, and fitting to the context of the problem. This finding implies that mathematization could reveal the way prospective mathematics teacher formulates contextual problems into mathematical problems.
\end{abstract}

Keywords: Mathematization, Prospective mathematics teacher, Problem-solving, Contextual problems

\section{A. Introduction}

Problem-solving is an essential ability for prospective mathematics teachers in daily life because it is a mean to develop logical, critical, and creative reasoning (Widjajanti, 2009). Therefore, a problem-solving ability is the focus of mathematical learning at all levels from elementary school to university (Depdiknas, 2004, 2006; Depdikbud, 2014). Bell (1981) and Posamentier and Krulik (2015) contend that problem-solving strategies commonly studied in mathematics and, in certain cases, can be transferred and applied in other problem-solving situations. Mathematics problem-solving can help prospective mathematics teachers improve their analytical ability and apply that ability to a variety of situations. Although the importance of problem-solving, prospective mathematics teachers' ability in problem-solving is still

\footnotetext{
${ }^{1}$ STKIP PGRI Sidoarjo, Sidoarjo, Jawa Timur, Indonesia, lestari.med@gmail.com

${ }^{2}$ Universitas Negeri Surabaya, Kampus Ketintang Surabaya, Jawa Timur, Indonesia

${ }^{3}$ STKIP Al Hikmah Surabaya, Kebonsari Elveka V street, Surabaya, Jawa Timur, Indonesia
} 
unsatisfied. Kusaeri (2010) and Patnani (2015) also found that prospective mathematics teachers were often confused when facing the problems.

Mathematization is an important process in mathematics problem-solving (Lestariningsih, Amin, Lukito, \& Lutfianto, 2017). Mathematization is not only done when prospective mathematics teachers create models or mathematical representations of a problem with real-life contexts but also when the process of solving these problems and interpreting them into reallife contexts (Gravemeijer \& Terwel, 2000; and OECD, 2013). Mathematization besides being an activity of mathematicians is also an activity of prospective mathematics teachers in understanding everyday situations using a mathematical approach.

Fosnot (2005) defines mathematization as a constructive process including observing patterns in special cases, analyzing the reasons for something happening, stating in some forms of generalization, and looking for flexibility in strategy making or proof. Roux (2010) argues that mathematization is the application of concepts, procedures, and methods developed in mathematics to objects or knowledge in either mathematics or other disciplines. In this research, mathematization is defined as the activity of transforming a problem expressed in a real-life context into a mathematical model or representation, then the completion of a mathematical model or representation is interpreted into a real-life context.

The real world is defined as everything that is outside mathematics, like everyday life and the environment (Siregar, 2016). The steps of mathematization in this study refer to Lestariningsih, Amin, Lukito, and Lutfianto (2018), namely 1) formulating a problem of realworld context into mathematical problems, 2) using the facts, concepts, procedures, and mathematical reasoning to obtain mathematical solution from mathematics problem, 3) interpreting the mathematical solution to the real world context in the initial problem, and 4) evaluating the solution to the real world context of the problem.

Mathematization as part of the process of solving mathematical problems or problems in everyday life makes it as an ability that must be owned by prospective mathematics teachers (Biccard \& Wessels, 2015, 2017). Studies about mathematics problem solving with a real problem situation (e.g., Blum \& Niss, 1991) show that situations have to be simplified, idealized, structured, subjected to appropriate conditions and assumptions, then this leads to a real model of the original situation. Prior studies on mathematization (e.g., Winter, 2014; Yilmaz \& Tkein-Dede, 2016; Botha \& Putten, 2018) have noted the importance of the notion in problem-solving and mathematics modeling activities.

Winter (2014) formulated five elements of mathematization, i.e., model formulation, story creation, intra mathematical work, interpretation/validation and pedagogy links to explore the nature of pre-service mathematical literacy teachers' problem-solving. It was found that prospective mathematics teachers' knowledge relating to model formulation, an aspect of extra mathematics connections, was weak. Nevertheless, there was the improvement in the elements of mathematization. Therefore, it needs to focus on correctly translating quantities from problem situations into mathematical models.

Yilmaz and Tkein-Dede (2016) defined mathematization as the focus of modeling process which consists of three components, i.e., identifying assumptions, identifying variables based on the assumptions and constructing mathematical model/s based on the relations among identified variables. The study aimed to analyze pre-service elementary mathematics teachers' mathematization competencies through their solution approaches while solving a modeling problem. It was found that the participants started to solve the problem by using only verbal explanations and then their expressions became more mathematical throughout the process. 
Botha and Putten (2018) studied four mathematics literacy teachers who facilitate mathematization in modeling situations in the classrooms. They focussed on horizontal mathematization that lies between context presentation and model formulation. It was revealed that some teachers are difficult to go beyond intra-mathematical problems and did not understand well the modeling process in general and the function and direction of mathematization in particular. The study implied that the process of mathematization in a modeling situation must be taught systematically and deliberately in pre-service mathematics teacher training.

Regarding the importance of mathematization for prospective mathematics teachers as the future teachers (Biccard \& Wessels, 2017; Winter, 2014; Lestariningsih, Amin, Lukito, \& Lutfianto, 2017), findings relating to the ability of prospective mathematics teachers in problem-solving (Kusaeri, 2010; Patnani, 2015) and the implication of Botha and Putten's (2018) study. We argue that it is essential to explore and understand the mathematization that used by prospective mathematics teacher when solving a problem in mathematics since prospective mathematics teacher will teach students learning and solving problems in mathematics that need mathematization. Thus, this study aims to explore mathematization underpinnings of prospective mathematics teacher in solving mathematics problems. Although referring to the similar notion of mathematization (OECD, 2013), the current study utilized different aspects of mathematization as Winter (2014) had. This study and prior studies (e.g., Winter, 2014; Yilmaz \& Tkein-Dede, 2016; Botha \& Putten, 2018) shared a common interest to understand mathematization as the important part of problem-solving and purpose to contribute to the field of the study.

\section{B. Methods}

This study employed explorative research with a qualitative approach because it explained mathematization activities that underpinning prospective mathematics teachers in solving contextual mathematics problems. The subject was a second-year prospective mathematics teacher with high mathematics ability because we would explore mathematization underpinnings of prospective mathematics teacher in mathematics problem-solving. The subject was selected from fifty-six prospective mathematics teachers by using mathematics ability test. After prospective mathematics teachers worked on a mathematics ability test, their answers were corrected and scored. The researchers scored prospective mathematics teachers' answers on each step of the problem-solving procedure by considering the complexity and level of difficulty of each item. The maximum score in this test was 100, and the minimum score was 0 . The time used to finish the mathematical ability test was 100 minutes. The subject in this study was a prospective mathematics teacher who scored more than 70 in the test and has good communication skill so we could explore the subject's mathematization in solving the contextual problem. The selected subject in this study then solved contextual problems for 15 minutes and continued with interviews.

The instruments used in this study were mathematical ability test, contextual problems, and interview guidelines. Mathematical ability test consisted of ten mathematical problems and was used to select the subject. The contextual problems consist of two questions that were adapted from mathematical literacy questions. The contextual problems were used to explore the mathematization that was done by the subject (Table 1). Then to explore in depth about the 
mathematization that has been done by the subject, we used semi-structured interview guidelines.

The mathematics problems in the test were adapted from basic and science mathematics problems used in national entrance selection of state universities in Indonesia (SBMPTN) year 2015 and 2016. The topics of the mathematics ability test are about (1) exponential, (2) inversion, (3) function, (4) arithmetic sequence, (5) geometric sequence, (6) root, (7) logarithms, (8) trigonometry, (9) transformation, and (10) probability. The original mathematics problems are in the form of multiple choices. In this study, we adjusted and converted the problems into the essay. To assure the quality of the test, we carried out construct validity, content validity, and face validity. The three types of validity were carried out by three validators who were experts in the field of mathematics education. We used interpretation of correlation coefficient proposed by Guilford (1956) for the criteria of validity of the test in Table 2. The average value from all validators for each item in indicators of three types of validation is calculated by summing the scores of the same indicator from each validator and then dividing by the number of validators who examined the test. Thus, we had 1,00 for validation result. It means that the mathematical ability test was categorized as very valid criteria. The contextual problems (Table 1) were also validated through construct, content, and face validity. The steps of validation were similar to validation of mathematics ability test. The validation conducted by three experts scored 1,00 which categorized as very valid.

Table 1. The contextual problems used for exploring subject's mathematization

\begin{tabular}{ll}
\hline Problem & \multicolumn{1}{c}{ Questions } \\
\hline First & In January, a new CD from the Alis and Mata bands were on sale. In February, CDs \\
Problem & $\begin{array}{l}\text { were also sold from the Pipi and Gigi bands. Graph 1 shows the number of CDs sold } \\
\text { from January to June. Manager of the Mata Band is concerned that many of the CDs }\end{array}$ \\
& $\begin{array}{l}\text { sold dropped from February to June. How many CDs of the Mata bands sold in July if } \\
\text { the same negative trend continues? }\end{array}$
\end{tabular}

CD sales per month

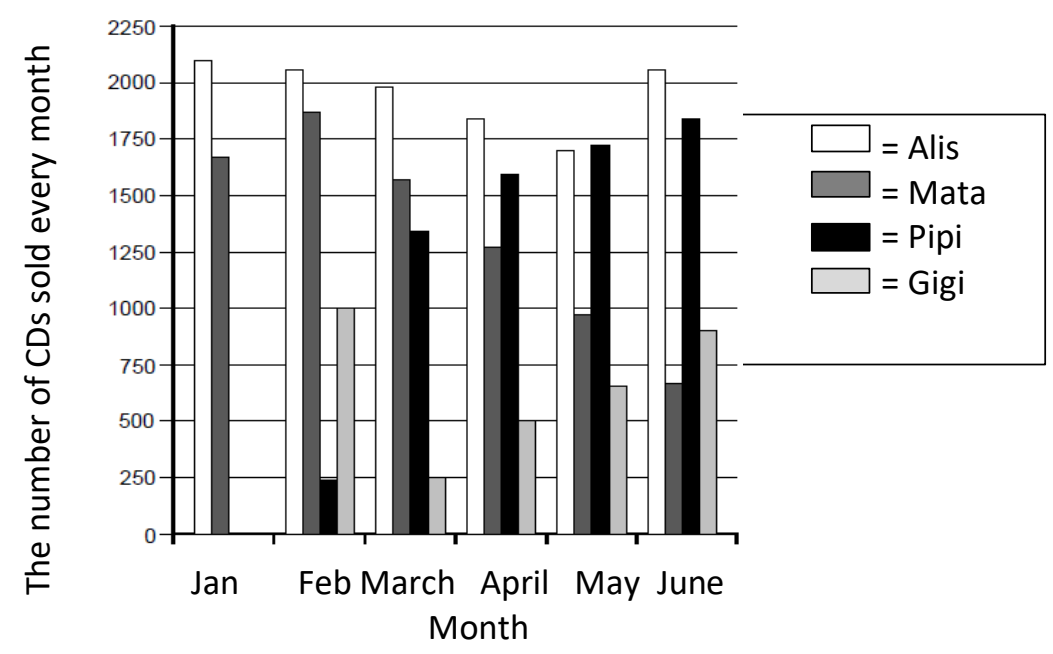

Graph 1. CD sales diagram
Second Rectangular field with $100 \mathrm{~m}$ in length and $50 \mathrm{~m}$ in width is prepared for music Problem concert audiences. Tickets are sold out, and the field is full of standing audiences. How many concert audiences are there? Explain!


Table 2. The interpretation of correlation coefficient for validity of the test

\begin{tabular}{cc}
\hline Correlation Coefficient & Interpretation \\
\hline $0,90<\mathrm{r}_{11} \leq 1,00$ & Very high correlation \\
$0,70<r_{11} \leq 0,90$ & High correlation \\
$0,40<r_{11} \leq 0,70$ & Moderate correlation \\
$0,20<r_{11} \leq 0,40$ & Low correlation \\
$r_{11} \leq 0,20$ & Slight correlation \\
\hline
\end{tabular}

Furthermore, analysis of interview data refers to Miles, Huberman, and Saldana (2014) which consists of three stages, namely data condensation, data presentation, and drawing the conclusion. Firstly, data condensation refers to the process of selecting data which relate to mathematization from field notes, interview transcripts, subject's work documents, and video recordings. Secondly, data from the first analysis was presented in the form of narrative text because the data was in the form of subject expressions related to mathematization activities when solving contextual problems and video recording. Thirdly, the presented data was interpreted and associated with the purpose of this study. The results of data interpretation were concluded to describe the mathematization which underpins prospective mathematics teacher in solving mathematics problems.

\section{Findings and Discussion}

In this part, we explored mathematization underpinnings of prospective mathematics teacher in mathematics problem-solving in the four parts relating to the step of mathematization, i.e., (1) formulating a problem of real-world context into mathematical problems, (2) using the facts, concepts, procedures and mathematical reasoning to obtain mathematical solution from mathematics problem, (3) interpreting the mathematical solution to the real world context in the initial problem, and (4) evaluating the solution to the real world context of the problem.

In the first step, the subject identified aspects of mathematics in the contextual problem using real-life context by presenting what is known or information in the form of verbal descriptions. In the first problem, the subject wrote down all the name of the bands in the problem (Figure 1a). While in the second problem, she wrote down the known length and width of the field in the answer sheet (Figure 1b).

Moreover, in the interview, the subject clarified the information contained in the problem. In the first problem, she said the number of CDs sold for Alis, Mata, Pipi, Gigi bands and sales diagrams from January to June, while in the second problem, she said information in the form of a rectangular field with a length of $100 \mathrm{~m}$ and a width of $50 \mathrm{~m}$ prepared for music concert audiences. Tickets are sold out, and the field is full of standing audiences.

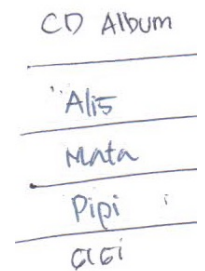

(a)

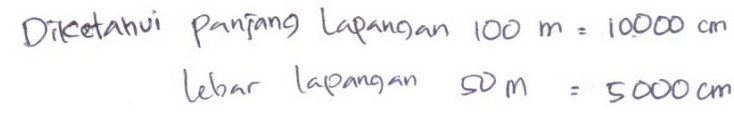

(b)

Figure 1. Information from the first problem 
Furthermore, the subject identified and brought up important variables according to real situation questions by expressing information in the problem using statements that have been understood. In the first problem, the subject stated that the important variables in the problem are the CD sales diagrams on the market, namely Alis, Mata, Pipi, and Gigi, and the number of CDs sold from month to month. Whereas in the second problem, she stated important variables in the problem is a rectangular field with mention of length and width. Transcripts of interviews between researchers (R) and subject (S) from first and second problems are presented in Table 2.

Table 2. The transcript of interviews

\begin{tabular}{|c|c|c|c|}
\hline \multicolumn{2}{|r|}{ First Problem } & \multicolumn{2}{|r|}{ Second Problem } \\
\hline $\mathrm{R}:$ & $\begin{array}{l}\text { Are there any important variables in } \\
\text { the problem? }\end{array}$ & $\mathrm{R}:$ & $\begin{array}{l}\text { Are there any important } \\
\text { variables in the problem? }\end{array}$ \\
\hline S: & $\begin{array}{l}\text { The diagram here explains the results } \\
\text { of selling } C D \text { s on the market. }\end{array}$ & S: & $\begin{array}{l}\text { The field has a } \\
\text { rectangular form with }\end{array}$ \\
\hline $\mathrm{R}:$ & Which one CD band that is sold? & & $100 \mathrm{~m}$ in length and $50 \mathrm{~m}$ \\
\hline S: & $\begin{array}{l}\text { There are Alis, Mata, Pipi and Gigi } \\
\text { bands. }\end{array}$ & & in width. \\
\hline $\mathrm{R}:$ & $\begin{array}{l}\text { Okay, are there any variables or other } \\
\text { relevant information that can be used } \\
\text { to solve the problem? }\end{array}$ & & \\
\hline S: & $\begin{array}{l}\text { Yes, there are the number of CDs sold } \\
\text { that must be used as guidelines from } \\
\text { month to month. }\end{array}$ & & \\
\hline
\end{tabular}

Then the subject represented the situation mathematically by using appropriate modeling. She also represented mathematical situations using symbols that she understood to clarify the problem and facilitated themselves in answering the problem. In the first problem, the subject reached the first step by stating the sales diagram of the CDs bands into the table. She did it to make the problem easier to solve, while from the second problem, she expressed the width and length of the field with symbols.

Based on the results of the analysis, in the step of formulating a problem using real-world context into a mathematical problem, we obtained the main category and subcategories. The main category was the way prospective mathematics teacher formulate contextual problems into mathematical problems. Next, there were three subcategories to formulate contextual problems, namely 1) describe verbally, 2) use understandable mathematical statements or symbols, 3 ) use appropriate modeling to clarify the problem and answer the questions.

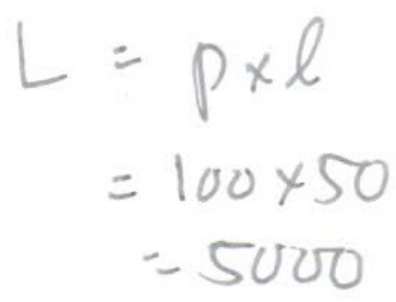

Figure 2. Prospective mathematics teacher's answer

In the second step,first problem the subject designed strategies to find mathematical solutions achieved by planning to determine the band that experienced a decline and increase in CD sales for the first problem. Then she estimated the number of CDs Mata band that were sold from February to June. She stated, "This is estimated first, which one is increasing, and 
which one is decreasing." For the second problem, the subject designed to calculate the area of the concert field and the area needed by each person.

Furthermore, prospective mathematics teacher applied facts, concepts, principles, procedures or mathematical reasoning when looking for solutions by: (1) building facts with using symbols $p$ and $l$ when stating the length and width or sequence to express the context contained in contextual problems, (2) using the concept of distance in the first problem and rectangle on the second problem to represent the context contained in contextual problems, and 3) using the principle to get a mathematical solution namely comparison in the first problem and area of square in the second problem. Also, prospective mathematics teacher used procedures, i.e. reduction algorithms, multiplication algorithms (Figure 2) and division algorithms to obtain mathematical solutions, and performed mathematical reasoning in the form of inductive reasoning using patterns for both problems.

In the steps of using facts, concepts, principles, procedures and mathematical reasoning to obtain a mathematical solution from mathematics problem, the main category was obtained; namely, prospective mathematics teacher constructing or using objects of learning mathematics to obtain mathematical solutions. Then there were two subcategories. Firstly, prospective mathematics teacher built or used objects of direct mathematics learning to get mathematical solutions, i.e., (1) establishing facts by applying symbols when declaring length and width or sequence to represent context, (2) using the concepts of distance and rectangles to represent context, and (3) using the comparison principle and the area of the rectangle to get a mathematical solution, (4) using procedures in the form of reduction algorithms, multiplication algorithms and division algorithms to get a mathematical solution. Secondly, prospective mathematics teacher uses indirect mathematical learning objects to obtain mathematical solutions by using mathematical reasoning in the form of inductive reasoning by using patterns to obtain mathematical solutions.

In the third step, the subject when interpreting mathematical solutions into real-world contexts in the initial questions were carried out by concluding the results achieved from the calculating operations that have been carried out. In the first problem, the subject concluded the solution. She said, "...I estimate the number of CD that sold between 300 and 350." While in the second problem, she concluded by stating that the number of audiences in the field is approximately 5000. From the interview, we had information that the subject predicted one person needs $1 \mathrm{~m}^{2}$. She argued, "In this problem, the length and the width of the field are known. Then she was asked how many audiences that watch the concert? Moreover, I answer approximately 5,000 audiences in the field because the area of the field is $5000 \mathrm{~m}^{2}$." In this case, the prospective mathematics teacher in interpreting mathematical solutions into realworld contexts in the initial problem was done by concluding the results obtained from the calculated operations that have been carried out.

In the last step, the subject evaluated the suitability between mathematical solutions in the context of real-world problems achieved by stating that the mathematical solutions were suitable with the context because she had read and reexamined the answers from beginning to end both in the first problem and in the second problem. The subject explained the reasons why the results or mathematical conclusions are appropriate in the context of the problem. It was achieved by stating that the conclusions made were appropriate to the context of the problem by mentioning the questions and answers. She said, "because it was explained earlier. How much is the number of concert audiences and the answer is 5000 audiences." 
The findings on mathematization underpinnings of prospective mathematics teacher in mathematics problem solving are in line with a study conducted by Blum \& Niss (1991) because mathematics problem-solving in this study was done by simplified, idealized, structured, subjected to appropriate conditions. The abilities that prospective mathematics teacher has in mastering problem-solving heuristics also support their ability in problemsolving (Lidinillah, 2011). Also, prospective mathematics teacher solved the contextual problem by performing representation, analysis, and interpretation (Oktaviyanthi \& Agus, 2018)

However, we found some crucial categories when prospective mathematics teacher did mathematization in mathematics problem solving that did not found in the previous study conducted by Winter (2014), Fosnot (2005), and Roux (2010). The main category was the way prospective mathematics teacher formulate contextual problems into mathematical problems (Figure 2). Then we found three subcategories, i.e., (1) describe verbally (Figure 1b), (2) use understood mathematical statements or symbols, i.e. $p$, and $l$ when stating the length and width, (3) use appropriate modelling to clarify the problem and facilitate the participant in answering questions when she presented field as rectangle.

Based on the findings specifically the main and sub-categories, mathematics educators need to develop prospective mathematics teachers' skills to describe verbally and creativity in symbolizing or modeling a contextual problem so that they can formulate contextual problems appropriately. We suggest the use of mathematization in mathematics problem solving because it could develop various strategies and knowledge relating to the model formulation in solving the problem from prospective mathematics teacher. Moreover, further studies about mathematization and problem-solving could also use high order thinking problems for prospective mathematics teacher.

\section{Conclusion}

Mathematization is a crucial process in solving mathematical literacy problems because through mathematization can be known the way prospective mathematics teacher formulates contextual problems into mathematical problems. The prospective mathematics teacher perform mathematization steps by (1) identifying the mathematical aspect of real situation problems, critical situations, and appropriate modelling, (2) planning mathematical solutions to strategies, (3) applying mathematical facts rules, algorithms, structures, or mathematical strategies when looking for solutions, and (4) interpreting mathematical solutions in real life context. We also found important category from this study, namely the way prospective mathematics teacher formulate contextual problems into mathematical problems. She used describe verbally, used understandable mathematical statements or symbols, and used appropriate modeling to clarify the problem. From findings, this study offers to extend knowledge about symbols and modeling in solving mathematics problem in mathematics education.

\section{Acknowledgment}

We want to thank the Ministry of Higher Education and Research on a research grant. 


\section{References}

Bell, F. H. (1981). Teaching and learning mathematics (in secondary school). (2nd ed). Dubuque, USA: William, C. Browm Company Publisher.

Biccard, P., \& Wessels, D. (2015). Student mathematical activity as a springboard to developing teacher didactisation practices. Pythagoras, 36 (2), 1-9. Doi: 10.4102/pythagoras.v36i2.294

Biccard, P., \& Wessels, D. (2017). Developing mathematisation practices in primary mathematics teaching through didactisation based teacher development. African Journal of Research in Mathematics, Science and Technology Education. 21(1), 61-73, Doi: 10.1080/18117295.2017.1283184

Blum, W., \& Niss, M. (1991). Applied mathematical problem solving, modelling, applications, and links to other subjects state, trends and issues in mathematics instruction. Educational studies in mathematics, 22(1), 37-68.

Botha, H. \& Putten, S.V. (2018). How mathematical literacy teachers facilitate mathematisation in modelling situations. African Journal of Research in Mathematics, Science and Technology Education, 22(1), 93-102. Doi: 10.1080/18117295.2018.1437337

Depdiknas. (2004). Draft Kurikulum 2004: Kerangka Dasar dan Standar Kompetensi Mata Pelajaran Matematika SMP/MTS. Jakarta: Balitbang Depdiknas.

Depdiknas. (2006). Standar Isi Kurikulum 2006. Jakarta: Departemen Pendidikan Nasional.

Depdikbud. (2014). Peraturan Menteri Pendidikan dan Kebudayaan No. 59 Tahun 2014 Kurikulum SMA lampiran III, PMP MTK SMA. Jakarta: Depdiknas.

Fosnot, C. T. (2005). Constructivism revisited: Implications and reflections. The Constructivist, 16(1), $1-17$.

Gravemeijer, K., \& Terwel, J. (2000). Hans Freudenthal: a mathematician on didactics and curriculum theory. Journal Curriculum Studies, 32(6), 777-796.

Guilford, J. P. (1956). Fundamental statistics in psychology and education. New York: Mc Graw-Hill Book Co. Inc.

Kusaeri. (2010). Profil kemampuan dasar matematika mahasiswa jurusan tadris pendidikan matematika fakultas tarbiyah. Qualita Ahsana, 8(2), 1-10.

Lestariningsih, L. Amin, S.M., Lukito, A., \& Lutfianto, M. (2017). Mathematisation of female student teachers with high mathematics ability in solving mathematical literacy problem with personal context. Proceeding of the 1st Mathematics, Informatics, Science, and Education International Conference (MISEIC) 2017, Universitas Negeri Surabaya.

Lestariningsih, L., Amin, S.M., Lukito, A., \& Lutfianto, M. (2018). Mathematisation of preservice teacher in solving higher order thinking problem. Proceeding of University of Muhammadiyah Malang's 1st International Conference of Mathematics Education. Atlantis Press: Advances in Social Science, Education and Humanities Research (ASSEHR), volume 160.

Lidinillah, D. A. M. (2011). Heuristik dalam pemecahan masalah matematika dan pembelajarannya di Sekolah Dasar. Bandung: Universitas Pendidikan Indonesia.

Miles, M.B., Huberman, A.M., \& Saldana, J. (2014). Qualitative data analysis: A methods sourcebook. Washington DC: Sage Publications, Inc.

OECD. (2013). PISA 2012 assessment and analytical framework: Mathematics, reading, science, problem solving and financial literacy. Paris: OECD Publishing. Retrieved from Doi. $10.1787 / 9789264190511$

Oktaviyanthi, R., \& Agus, R. N. (2018). Peningkatan kemampuan pemecahan masalah mahasiswa calon guru melalui keterampilan fungsional matematis. Beta: Jurnal Tadris Matematika, 11(1), 1-19.

Patnani, M. (2015). Upaya meningkatkan kemampuan problem solving pada mahasiswa. Journal Psikogenesis, 1(2), 130-142.

Posamentier, A. S., \& Krulik, S. (2015). Problem-solving strategies in mathematics: From common approaches to exemplary strategies (Vol. 1). World Scientific Publishing Company.

Roux, S. (2010). Forms of mathematization (14 th-17 th Centuries). Early Science and Medicine, $15(4 / 5), 319-337$.

Siregar, N. F. (2016). Pemahaman dan komunikasi matematis dalam pembelajaran matematika realistik. Logaritma. 4(1), 17-36. 
Lestariningsih, Amin, S.M., Lukito, A., \& Lutfianto, M.

Widjajanti, D. B. (2009). Kemampuan pemecahan masalah matematis mahasiswa calon guru matematika: apa dan bagaimana mengembangkannya. Prosiding Seminar Nasional Matematika dan Pendidikan Matematika 2009. Universitas Negeri Yogyakarta

Winter, M.M.J. (2014). Pre-service teacher learning and practice for mathematical literacy. Johannesburg: University of the Witwatersrand.

Yilmaz, S. \& Tekin-Dede, A. (2016). Mathematization competencies of pre-service elementary mathematics teachers in the mathematical modelling process. International Journal of Education in Mathematics, Science and Technology, 4(4), 284-298. Doi:10.18404/ijemst.39145 